\title{
Future Career in Hospitality Industry Based on Internship Experience: A Principal Component Analysis
}

\author{
Samia Afrin Shetu ${ }^{1}$ Takrima Sayeda ${ }^{2 *}$ \\ 1. Department of Tourism \& Hospitality Management, University of Dhaka \\ 2. Department of Tourism \& Hospitality Management, University of Dhaka
}

\begin{abstract}
The purpose of this research is to investigate the factors associated with internship programs and the relationships between internship experiences in tourism and hospitality industry and aspect of future career in the same industry. A principal component analysis was used to determine the degree of impact of internship program planning, industry's involvement and students' self commitment. Effective planning of the internship program played a positive and influential role in deciding future career in tourism and hospitality industry. The extent of industry involvement during the internship period mediated internship students' confidence in tourism industry. However, students' self-commitment have found rather low to join the industry.
\end{abstract}

Keywords: Internship program, Tourism and Hospitality industry, Factor Analysis

DOI: $10.7176 / \mathrm{EJBM} / 12-3-22$

Publication date: January $31^{\text {st }} 2020$

\section{Introduction}

Experience based knowledge interfaces our theoretical understanding with practical learning. When practical implication backs the theoretical knowledge, the learning remains long lasting. More specifically the service sector like tourism and hospitality needs experience-based practices to make its circle fulfilled. Experiential education has an extended and significant journey in tertiary level education; internship is one of them (Beggs, Ross, \& Goodwin, 2008). It is termed as "Windows to the Real World" or "Supervised Work Experienced" or "Bridge to the Real World" (Chen \& Shen, 2012). All around the world travel and tourism industry has tremendous effect on economic development. According to World travel and tourism Council (WTTC, 2018), travel and tourism's direct contribution to GDP all over the world was 21.5 (US\$bn) and in Bangladesh it was 5.3 (US\$bn). Travel and tourism's direct contribution to employment all over the world average was 937.5 thousand and Bangladesh average was 1178.4 thousand. This advancement shows that, travel and tourism education, curricula development, training, educational courses, and programs are very much needed to produce quality graduates who will be capable to serve this industry (Williams and Buswell, 2003).

Hospitality educationalists think that experiential learning component should be included in the curriculum and it help to develop managerial skill (Petrillose \& Montgomery, 1998). However the success of such internship program depends on the satisfaction of the students (Chen \& Shen, 2012). Ju, Emenheiser, Clayton, and Reynold (1998) discovered that students' perception about their internship experience had eight dimensions: professional skills development, leadership development, general knowledge improvement, future career marketing, selfactualization, relationship and supervisor, structure of the program and structure of the academic courses. They also indicated two depended variables - students' commitment to continue to work in the hospitality sector and their satisfaction level for successfully completing the internship. The industry that has worth more than a multibillion dollar may face huge risk without highly educated professionals (Williams, 1990). The purpose of the study is to understand the factors in internship program, that can encourage inter students to have future career in tourism and hospitality industry.

\section{Literature Review}

Internship is an outstanding prospect to acquire exchangeable skills and the precise knowledge that is required in today's workstation (Busby, 2003). Though there are many controversies among the scholars, several studies have considered hospitality curriculum and integrated operational and managerial skills are needed for professional success (Baum, 1991 \& Dopson and Nelson, 2003). Li and Kivela (1988) conducted a study on industry practitioners, educators and students of USA. He surveyed human resource directors and managers in 40 food service operations and educators and students from 200 institutions. They asserted that, business communication and managerial skills are the most important factors that they should acquire. Whereas some scholars suggested that working knowledge of product or services were significant for success (Kay and Russette, 2000). Okeiyi et 
al.(1994) advocated that interpersonal relations and managerial skills are more vital for success. Burgidge (1994) studied on student' perception and preparation for success and came up with finding that revolutionize is compulsory in educational intuitions and training programs. Kay and Russette (2000) specified that six skills are required for hospitality-management competency and these are: identification of customer problems; having passion to serve; upholding professional and moral principles; promoting trust; and adapting change. Moreover, Tas et al. (1996), found that for managing a property a manager trainee should have human relation skill, crisis management skill, operational efficiency skill and knowledge of record-keeping and legal regulations. Finally Dopson and Tas (2004) specified that the curriculum of hospitality schools should not only motivate students to learn essential skills for running business but also should have substantial knowledge to manage human resources. Other scholars claim three major components, such as substantive knowledge, skills, and values are needed during developing a curriculum (Dopson and Tas, 2004; Gursoy and Swanger, 2004, 2005).

Many students consider internship as a pathway for their future career and the experiences they get from internship may facilitate their desire to work in the hospitality sector (Tse, 2010). During school, internships help to get realistic expectation of perspective career by letting hospitality students experiencing the actual job circumstances (Lam \& Ching, 2007). Before participating in the internship, knowing the responsibilities of interns and the intern supervisors can be the two elements that can lead to a successful internship (Beggs, Ross, \& Goodwin, 2008; Young \& Hurlic, 2007). This experiential learning have several benefits for the student. Lee (2007) has addressed that experiential learning increases the understanding of how organizations function and the ability to view career expectations realistically. Additionally it increases network of professional contacts, increases skill to take initiative and adjust to change, develops leadership skills, and increases financial management skills (Chen, et al., 2009). Some researchers have found that an effective internship program can retain students as their employees, accelerate their passion and lessen their worries about future career (Ju et al., 1998). Collins (2002) surveyed 113 students' (senior); 76 industry professionals and 6 university participants with three sets of questionnaire. The finding was that students' may have the opportunity to get employed in the same organization if they successfully completed the internship program after their graduation. Additionally his findings were backed by the data of 62 organizations who hired their interns after the internship program. Not only that, experiences gathered from internship helps to build confidence among the students in career progress (Ko, 2007). Students from hospitality and tourism usually kept higher expectations but in reality their primary expectations did not meet with their actual satisfaction (Dickerson, 2009). It has been proved that student expectations are mainly molded by the prior perception of the internship, that are influenced by some of the factors including: academic theories, sources of information, prior industry experience, training by the university and the willingness of the student (Jiang \& Tribe, 2009,Singh \& Dutta, 2010). Chen et al. (2009) conducted a study on 632 undergraduate students of Taiwan to develop the emotional personnel satisfaction and he used descriptive statistics and factor analysis to analyze the data. He asserted that, demand of the job; emotional support and social support are the prime factors that can satisfy interns and stimulate their intention to stay in the industry. Many studies had been done to identify the motivating factors for studying tourism and hospitality and the major factors identified as are interest in tourism, parental influence, cultural development, travel capability and the hypothesis that a degree produces low level graduates with the guarantee of 'quick way to the top' (Chak-keung Wong \& Jing Liu, 2010 \& Kim \& Park, 2013). Wan \& Kong (2011) studied on career perception of undergraduate gaming management student of Morocco, where 81 students of game management were surveyed through questionnaire. Descriptive study, two t-test and variance analysis were done to analyze the data. The finding of the study was that, $63 \%$ of the respondent said that teachers and gaming members played a great role in choosing their career in this industry. About $74 \%$ of the respondent gave their consent to come back to work in the same industry after graduation. Besides, internship programs help them to get a screening of workplaces, reduce the expectation gap, provide career satisfaction and employee retention (Dickerson, 2009). Structured internship might have a great impact on the performances of the students and can increase the retention rate by decreasing the turnover rate (Siegel, Blackwood \& Landy, 2010). Internship advisors supervise the students and play the role of a connector among students, employees and schools to handle any matter (Collins, 2002; Lee \& Chao, 2008). So their role is undoubtedly important.

However, several studies have do find that, bitter internship experiences influence students unwillingness to work in the hospitality sector(Barron \& Maxwell, 1993 \& Callan, 1997). Zopiaits (2007) conducted a study on three prominent stakeholders of internship program to investigate different issues. The three stakeholders are students, educators and professionals. He conducted the research in "methodological triangulation". His target population was all the students of Cyprus (with at least one internship experience) and to avoid over-representation, he used stratified random sample. He surveyed 150 hospitality professional who are associated with the internship. Finally, he came up with the findings that hospitality educators merely allocate a placement to their interns, overlooking the other issues: hospitality professionals are unable to provide interns meaningful works; no on-the-job supervisor 
and positive environment. Additionally government policies are also responsible for widening the interns' expectation gap. Thus internship programs failed to motivate potential employees (interns) to join the hospitality sector after completing the study. Earlier studies have revealed that experienced hospitality students within the profession are much less devoted to the hospitality industry (Teng, 2008). Pressures from the job is considered as one of the vital reasons for this deviation while some believe that the opportunity to express the emotions must be a part of the job (Ashforth\& Humphrey, 1993; Morris \& Feldman, 1997). Teng(2008) has also found that workrelated stress can possibly affect the work performance of employees, regardless of full time employee or internship posts in hospitality sector. Richardson (2008) conducted an online survey on 86 students from hospitality sector of Australia to find out the attitude and perceptions of current undergraduate tourism and hospitality students. He divided the survey in three sections: demographics; career aspirations; and a multidimensional and multi-item attitude scale. The upsetting finding is that, after graduation about 33.7\% (more than one-third) of the respondents opined that they are unwilling to work in the tourism and hospitality industry and the "working experience in the industry" is the main reason behind this refusal. Graduate psychological training on students have found that female students have higher stress scores than males in terms of the impact of emotional, financial, and academic stressors. Several studies concluded that gap between expectation and real experience is the prime reason for interns to leave the hospitality industry. When an internship program can't fulfill the expectations of an intern, he/she might lose interest to work in tourism and hospitality sector after completing his/her graduation (Waryszak, 1999). Likewise, many hospitality students get less fascinated to pick this sector as their first choice to start career after having exposure to the subject and work experience (Jenkins, 2001). Thus, an unsuccessful internship program can discourage students to enter into the hospitality sector and the effective one can encourage the students to enter and work up to the advancement.

\section{Methodology}

\subsection{Instrument design and development}

The questionnaire was developed based on a comprehensive review of the literature. The three-section questionnaire included 12 questions on Internship Program design, 8 questions included Industry Involvement and 8 questions included on Students' Self Commitment and 5 questions about students' overall satisfaction about the internship program including and demographic characteristics their age, marital status, timing and duration of their internship. The items were adopted from other research questionnaires assessing job satisfaction, on the job training, industry involvement and overall satisfaction of the students. In the questionnaire students were asked to reveal their perception on a five-pointLikert scale. Statements are rated on a scale from (1) strongly disagree, (2) disagree, (3) neutral, (4) agree, (5) strongly agree.

\subsection{Sampling and Data Collection}

A convenience sample of intern students was selected from few hospitality institutions in Dhaka City, who take undergraduate or graduate students as their interns for 3 to 6 months duration. Only female inter students were taken into consideration. From 60 copies of questionnaire, a total of 50 copies were completed and returned. Thus the sample size is 50 .

\section{Data Analysis}

The collected data were analyzed with statistical package STATA. The demographic information of the participants and their responses to internship questions were summarized using descriptive statistics. The 28 item perception questions were subjected to the factor analysis using principal component method with varimax rotation to group the related items into components. The factor loadings, Eigenvalues, and percent of variances explained by each component were reported. Items that have factor loadings greater than 0.5 were retained for factor grouping.

\subsection{Results and Discussion}

Descriptive statistics of the respondents are presented in Table 1. A total of 50 copies of questionnaires were collected. The study solely administered on female interns to observe their perceptions regarding the internship program and their future career in tourism and hospitality sector. The major intern periods for the students were during the semester break (40\%). Two -third of the internship duration is in between one to four months. Intern students are mainly coming from public universities $(72 \%)$. The season behind the influx of public university students is that they have full fledged and independent department for tourism and hospitality management. In case of placement of the interns in the hotels, majority of them are concentrated in front office $(30 \%)$, after that marketing \& sales $(28 \%)$ and then food \& beverages $(22 \%)$.

Table 2 presents the mean scores and standard deviation of the three major factors tested in the study. It shows that Internship Program Planning has the highest factor mean score of 4.04. It also has the smallest standard deviation, with a value of 0.79 , which means that its individual sub-factor scores are almost concentrated and very close to 
its mean. This explains that the respondents perceived internship program planning as an important factor in their internship and it shows that schools play an important role in the internship experience of the respondents. The second highest factor is Industry Involvement with a mean score of 3.91. Based on the previous results, training obtained the highest score among the sub-factors of industry involvement. This shows that the respondents greatly value the training program that they received from their supervisors. A poor training program may affect the quality of their internship. The involvement of the industry itself affects the internship experience since this is where students apply what they have learned in class and where they would be exposed in the corporate world in which they could learn and develop proper skills appropriate for the industry. Lastly, Students ${ }^{\text {ee }}$ Self-Commitment is the least appreciated factor by the respondents with a mean score of 3.22. The results may show that the students are highly dedicated to learn, but it does not greatly influence their internship experience.

A factor analysis was utilized to derive the scope of the internship experience to choose hospitality industry as their future profession developed by Chen \& Shen (2012). These 28 items were seen as the attributes that would define students' future job perception based on their internship experience. The determinants were factor-analyzed using a principal component analysis using orthogonal varimax rotation. Only factors with an Eigenvalue of 1 or higher were taken. The factors were identified and named. The factors for future job determination were: internship planning program, industry involvement and students' self commitment. All the items with factors loading above 0.5 were included.

Three components were extracted in order to determine the factors loadings of the three pre determined factors. The total values present the grouping of the factors that received the highest scores. Percentage of variance shows that internship planning program accounts for $26.40 \%$ of the variability in all the assessed factors. This can be related to the results of the factor mean scores as shown earlier, where internship planning program received the highest mean score out of three factors. Conversely, industry involvement and students' self commitment accounts for $20.86 \%$ and $9.59 \%$ respectively. Similar with the results with factor mean scores, industry involvement obtained second highest score and students' self commitment received the lowest score. The results show that the three factors explained $56.85 \%$ of the overall variance.

A reliability test was also conducted in the study and it shows that the obtained Cronbach's alpha value is 0.9304 , which is a relatively high value since a Cronbach's alpha value of 0.75 is usually the standard minimum requirement to be able to conclude good scale reliability. Therefore, it is concluded and justified that the questionnaire containing 33 scale questions is a reliable instrument in measuring the factors that influence students' satisfaction with their internship experience and their willingness to stay in the tourism and hospitality industry.

\section{Conclusion}

The findings show that each of the three factors is significantly different to one another and the respondents see at least one of the factors as the most important in their internship experience. For this reason, the internship program planning is the most important factor for the respondents. Since the schools mostly do the program planning, this shows that schools have the most influence in providing a good internship program to their students. The design of the internship program is also essential for the respondents. Holding career consultations helps them to gain ideas where they would want to have their internship. In terms of the industry's involvement in the internship experience of the respondents, training is important for them. Majority of them are eager to learn more skills and knowledge during their internship training. They believe that rotation opportunities are essential for their training where they can gain more knowledge and skills by working with the different departments of the establishment. Intern students want to have a training program where they can learn important skills that they can use in their chosen industry. Hence, they do not see their internship as stressful, exhausting and a waste of time. It actually strengthens their abilities and improves their values towards the industry. Overall, the respondents were highly satisfied with their internship experience. It leads them to recommend other people to engage in the tourism and hospitality industry after they had their internship. Few of the respondents considered having a career transition. Majority of them decided to pursue a career in the industry after graduation. But, it is still important to note that $18 \%$ of the 50 respondents chose not to join the industry after they had their internship. In some way, their internship experience influences them to turn away from the industry.

The following limitations were inherent in the study. First, the study was conducted in tourism and hospitality institutions. To overcome this limitation, future research findings should compare students in both hospitality institutions and universities. Second, the population in this research was limited to northern Dhaka city only. Therefore, the results from the study may not be generalized beyond this population. The cross comparison of students' internship perception might also be undertaken to reveal whether results differ from city to city. Third, it is administered only on female interns. Had there been male students, the results might have different. In addition, 
the relationship of internship experience and employees' willingness to stay working in the hospitality industry requires more research.

\section{References}

Ashforth, B. E., \& Humphrey, R. H. (1993), "Emotional labor in service roles: The influence of identity", The Academy of Management Review, 18(1), 88-115.

Barron, P., \& Maxwell, G. (1993), "Hospitality management students' image of the hospitality industry", International Journal of Hospitality Management, 5(5), 5-8.

Baum, T. (1991), "The US and the UK: comparing expectations of management trainees", Cornell Hotel \& Restaurant Administration Quarterly, Vol. 32 No. 2, pp. 79-84.

Beggs, B., Ross, C. M. \& Goodwin, B. (2008), "A Comparison of Student and Practitioner Perspectives of the Travel and Tourism Internship", Journal of Hospitality, Leisure, Sport \& Tourism Education, Vol. 7, No. 1. ISSN: $1473-8376$.

Berta, D. (2003), "Study shows students eager to work in hospitality", Nation's Restaurant News, 24th March, 16.

Burgidge, D.J. (1994), "Student perception of preparation for success: a view from Europe", Journal of Hospitality and Tourism Educators, Vol. 6 No. 4, pp. 45-50.

Busby, G. (2003), "Tourism degree internships: a longitudinal study", Journal of Vocational Education and Training, 55(3), 319-334.

Busby, G. (2005), "Work experience and industrial links", In: D. Airey, \& J. Tribe (Eds.), An International Handbook of Tourism Education (pp. 93-107). Oxford Elsevier.

Callan, R. (1997), "Supervised work experience in Europe: a profile of UK undergraduate perceptions", International journal of Contemporary Hospitality Management, 9(1), 35-39.

Carey, M.L. and Franklin, J.C. (1991), "Industry output and job growth continues to slow into the next century", Monthly Labor Review, Vol. 114 No. 11, p. 45.

Chak-keung Wong, S., \& Jing Liu, G. (2010), "Will parental influences affect career choice? Evidence from hospitality and tourism management students in China", International Journal of Contemporary Hospitality Management, 22(1), 82-102.

Chen, et. al, (2009), "Job demand, emotional awareness, and Job satisfaction in internships: the moderating effect of social support”, Social Behavior and Personality, 37(10), 1429-1440 (C) Society for Personality Research (Inc.) Retrieved from, DOI 10.2224/sbp.2009.37.10.1429

Chen, T. \& Shen, C. (2012), "Today's interns tomorrow's practitioner?-The influence of internship programs on students' career development in the Hospitality Industry", Journal of Hospitality, Leisure, Sport \& Tourism Education, 11 29-40.

Christou, E. (2002), "Revisiting competencies for hospitality management: contemporary views of the stakeholders", Journal of Hospitality and Tourism Education, Vol. 14 No. 1, pp. 25-32.

Collins, A. B. (2002), "Gateway to the real world, industrial training: dilemmas and problems", Tourism Management, 23, 93-96.

Dikerson, J. P. (2009), "The realistic preview may not yield career satisfaction", International journal of Hospitality Management, 28, 297-299.

Dopson, L.R. and Nelson, A.A. (2003), "Future of hotel education: required program content areas for graduates of US hospitality programs beyond the year 2000 - Part II", Journal of Hospitality and Tourism Education, Vol. 15 No. 3, pp. 11-17.

Dopson, L.R. and Tas, R.F. (2004). "A practical approach to curriculum development: a case study”, Journal of Hospitality and Tourism Education, Vol. 16 No. 1, pp. 39-46.

Farkas, D. (1993), “Trained in vain?”, Restaurant Hospitality, Vol. 68.

Feiertag, H. (1998), “College students can be bright prospects for prospecting”, Hotel \& Motel Management, Vol. 213 No. 11, p. 20.

Gursoy, D. and Swanger, N. (2004), "An industry-driven model of hospitality curriculum for programs housed in accredited colleges of business", Journal of Hospitality and Tourism Education, Vol. 16 No. 4, pp. 13-20.

Gursoy, D. and Swanger, N. (2004), "An industry-driven model of hospitality curriculum for programs housed in accredited colleges of business", Journal of Hospitality and Tourism Education, Vol. 16 No. 4, pp. 13-20.

Gursoy, D. and Swanger, N. (2005), “An industry-driven model of hospitality curriculum for programs housed in accredited colleges of business - Part II”, Journal of Hospitality and Tourism Education, Vol. 17 No. 2, pp. 46-56.

Gursoy, D. and Swanger, N. (2005), “An industry-driven model of hospitality curriculum for programs housed in accredited colleges of business - Part II", Journal of Hospitality and Tourism Education, Vol. 17 No. 2, pp. 46-56.

Jenkin, A. K. (2001), "Making a career of it? Hospitality students' Future perspectives: an Anglo-Dutch study", 
International journal of Contemporary Hospitality Management, 13(1), 13-20.

Jiang, B., \& Tribe, J. (2009), “Tourism jobs-short lived professions: Student attitudes towards tourism careers in China”, Journal of Hospitality, Leisure, Sports and Tourism Education (Pre-2012), 8(1), 4.

Ju, J., Emenheiser, D. A., Clayton, H. R., \& Reynolds, J. (1998), “Korean students' perceptions of the effectiveness of their internship experiences in the hospitality industry in Korea", Asia Pacific Journal of Tourism Research, 3(1), 37-44.

Kay, C. and Russette, J. (2000), "Hospitality-management competencies", Cornell Hotel \& Restaurant Administration Quarterly, Vol. 41 No. 2, pp. 52-63.

Kim, H. B., \& Park, E. J. (2013), "The role of social experience in undergraduates' career perceptions through internships", Journal of Hospitality, Leisure, Sport \& Tourism Education, 12(1), 70-78.

Knutson, B.J. and Patton, M.E. (1992), "How prepared am I to succeed in the hospitality industry? What the students are telling us", Hospitality and Tourism Educator, Vol.4 No.3, pp.38-43.

Lam, T., \& Ching, L. (2007), "An exploratory study of an internship program: The case of Hong Kong students," International Journal of Hospitality Management, 26(2), 336-351.

Li, L. and Kivela, J.J. (1988), "Different perceptions between hotel managers and students regarding levels of competency demonstrated by hospitality degree graduates", Australian Journal of Hospitality Management, Vol. 5 No. 2, pp. 47-54.

Morris, J. A., \& Feldman, D. C. (1997), "Managing emotions in the workplace", Journal of Managerial Issues, 9(3), 257-274.

Okeiyi, E., Finley, D. and Postel, R.T. (1994), "Food and beverage management competencies: educator, industry, and student perspectives”, Hospitality and Tourism Educator, Vol. 6 No. 4, pp. 37-40.

Petrillose, M. J., \& Montgomery, T. (1998), “An exploratory study of internship practices in hospitality education and industry's perceptions of the importance of internships in hospitality curriculum," Journal of Hospitality and Tourism Education, 9(4), 46-51.

Purcell, K. (1993), "Equal opportunities in the hospitality industry: custom and credentials", International Journal of Hospitality Management, Vol. 12 No. 2, pp. 127-40.

Richardson, S. (2008), “Undergraduate tourism and hospitality students' attitudes toward a career in the industry: a preliminary investigation”, Journal of Business education, 6(1), 5-12.

Siegel, P. H., Blackwood, B. J., \& Landy, S. D. (2010), “Tax professional internships and subsequent professional performance", American Journal of Business Education, 3(5), 51-56.

Singh, A., \& Dutta, K. (2010), "Hospitality internship placements: Analysis for United Kingdom and India," Journal of Services Research, 10(1), 85.

Tas, R.F. (1988), “Teaching future managers”, Cornell Hotel \& Restaurant Administration Quarterly, Vol. 29 No. 2, pp. 41-3.

Tas, R.F., LaBrecque, S.V. and Clayton, H.R. (1996), "Property-management competencies for management trainees", Cornell Hotel \& Restaurant Administration Quarterly, Vol.37 No.4, pp. 90-6.

Teng, C. C. (2008), "The effects of personality traits and attitudes on student uptake in hospitality employment", International Journal of Hospitality Management, 27(1), 76-86.

Tse, T. S. M. (2010), "What do hospitality students find important about internships?", Journal of Teaching in Travel \& Tourism, 10(3), 251-264.

Wan, Y. K., P., \& Kong, W. H. (2011), "Career perceptions of undergraduate gaming management students", Journal of Teaching in Travel \& Tourism, 11(4), 367-391.

Waryszak, R. Z. (1990), "Student's expectations from there cooperative education placements in the hospitality industry: an international perspective", Journal of Business education, 41(1), 33-40.

West, A. J., \& Jameson, S. M. (1990), "Supervised work experience in graduate employment", Journal of European Industrial Training, 14(3), 29-32.

Williams, A.G. (1990), “So...what's wrong with hospitality education?”, Florida International University Hospitality Review, 8(1), 72-82.

Williams, C. and Buswell, J. (2003), "Service Quality in Leisure and Tourism”, Cambridge, MA: CABI Publishing.

World Travel \& Tourism Council 2018. Retrieved from https:/www.wttc.org/economic-impact/countryanalysis/country-reports/ on 22th June, 2019 at 9:20 pm.

Yıldırım, A. (2002), "Turizm eğitimi [Tourism education]”, Ankara: Aren Ajans.

Young, A. M., \& Hurlic, D. (2007), "Gender enactment at work: The importance of gender and gender-related behavior to person-organizational fit and career decisions”, Journal of Managerial Psychology, 22(2), 168187.

Zopiatis, A. (2007), "Hospitality internships in Cyprus: a genuine academic experience or a continuing frustration?," International journal of Contemporary Hospitality Management, 19(1), 65-77. 
Table 1

Description Statistics of the Internship Students $(n=50)$

\begin{tabular}{|c|c|c|}
\hline Variable & Frequency & Percentage \\
\hline $\begin{array}{l}\text { Age } \\
19-24 \\
25-29 \\
30-35 \\
>35 \\
\end{array}$ & $\begin{array}{l}21 \\
17 \\
10 \\
2\end{array}$ & $\begin{array}{l}42 \\
34 \\
20 \\
4\end{array}$ \\
\hline $\begin{array}{l}\text { Internship time } \\
\text { After Graduation } \\
\text { During Semester } \\
\text { Job } \\
\text { Semester Break } \\
\text { Others }\end{array}$ & $\begin{array}{l}13 \\
10 \\
4 \\
20 \\
3\end{array}$ & $\begin{array}{l}26 \\
20 \\
8 \\
40 \\
6\end{array}$ \\
\hline $\begin{array}{l}\text { Origin of Intern Students } \\
\text { Public Universities } \\
\text { Private Universities } \\
\text { Govt. Entity }\end{array}$ & $\begin{array}{l}36 \\
11 \\
3\end{array}$ & $\begin{array}{l}72 \\
22 \\
6\end{array}$ \\
\hline $\begin{array}{l}\text { Internship Duration } \\
1-4 \text { months } \\
5-8 \text { months } \\
9-12 \text { months } \\
>12 \text { months }\end{array}$ & $\begin{array}{l}33 \\
10 \\
1 \\
5\end{array}$ & $\begin{array}{l}66 \\
20 \\
2 \\
10\end{array}$ \\
\hline $\begin{array}{l}\text { Placement Area } \\
\text { Food \& Beverage } \\
\text { Front Office } \\
\text { Marketing \& Sales } \\
\text { Finance } \\
\text { Housekeeping } \\
\text { Human Resource } \\
\text { Travel Agent } \\
\text { Tour Operator }\end{array}$ & $\begin{array}{l}11 \\
15 \\
14 \\
2 \\
4 \\
4 \\
4 \\
3\end{array}$ & $\begin{array}{l}22 \\
30 \\
28 \\
4 \\
8 \\
8 \\
8 \\
6\end{array}$ \\
\hline
\end{tabular}

Table 2: Factor Mean Scores and Standard Deviation

\begin{tabular}{|l|l|l|l|}
\hline Factors influencing & Mean & Rank & Standard Deviation \\
\hline $\begin{array}{l}\text { Internship Program } \\
\text { Planning }\end{array}$ & 4.04 & 1 & 0.79 \\
\hline Industry Involvement self & 3.91 & 2 & 0.845 \\
\hline $\begin{array}{l}\text { Students' } \\
\text { commitment }\end{array}$ & 3.22 & 0.97 \\
\hline
\end{tabular}


Table 3: Principal Component Analysis of Factors influencing Internship Students' Job Selection

\begin{tabular}{|c|c|c|c|c|c|c|}
\hline \multirow[t]{2}{*}{ Component } & \multicolumn{3}{|c|}{ Initial Eigenvalues } & \multicolumn{3}{|c|}{ Rotation sums of squared Loadings } \\
\hline & Eigenvalues & $\begin{array}{c}\% \text { of } \\
\text { Varaince }\end{array}$ & Cumulative $\%$ & Total & $\begin{array}{c}\% \text { of } \\
\text { Variance }\end{array}$ & Cumulative $\%$ \\
\hline 1 & 12.0914 & 0.4318 & 0.4318 & 7.39215 & 0.2640 & 0.2640 \\
\hline 2 & 2.69555 & 0.0963 & 0.5281 & 5.84077 & 0.2086 & 0.4726 \\
\hline 3 & 2.11669 & 0.0756 & 0.6037 & 2.684 & 0.0959 & 0.5685 \\
\hline 4 & 1.46181 & 0.0522 & 0.6559 & & & \\
\hline 5 & 1.2851 & 0.0459 & 0.7018 & & & \\
\hline 6 & 1.07833 & 0.0385 & 0.7403 & & & \\
\hline 7 & 1.02243 & 0.0365 & 0.8058 & & & \\
\hline 8 & 0.812209 & 0.0290 & 0.8318 & & & \\
\hline 9 & 0.728588 & 0.0260 & 0.8557 & & & \\
\hline 10 & 0.667755 & 0.0238 & 0.8762 & & & \\
\hline 11 & 0.574304 & 0.0205 & 0.8942 & & & \\
\hline 12 & 0.50361 & 0.0180 & 0.9100 & & & \\
\hline 13 & 0.444159 & 0.0159 & 0.9243 & & & \\
\hline 14 & 0.398862 & 0.0142 & 0.9379 & & & \\
\hline 15 & 0.381034 & 0.0136 & 0.9482 & & & \\
\hline 16 & 0.289038 & 0.0103 & 0.9576 & & & \\
\hline 17 & 0.262624 & 0.0094 & 0.9660 & & & \\
\hline 18 & 0.234127 & 0.0084 & 0.9576 & & & \\
\hline 19 & 0.203202 & 0.0073 & 0.9660 & & & \\
\hline 20 & 0.162909 & 0.0058 & 0.9732 & & & \\
\hline 21 & 0.37104 & 0.0049 & 0.9790 & & & \\
\hline 22 & 0.103705 & 0.0037 & 0.9839 & & & \\
\hline 23 & 0.0777832 & 0.0028 & 0.9876 & & & \\
\hline 24 & 0.0731755 & 0.0026 & 0.9904 & & & \\
\hline 25 & 0.0700491 & 0.0025 & 0.9930 & & & \\
\hline 26 & 0.0544179 & 0.0019 & 0.9955 & & & \\
\hline 27 & 0.0479013 & 0.0017 & 0.999 & & & \\
\hline 28 & 0.0227345 & 0.0008 & 1.0000 & & & \\
\hline
\end{tabular}

